2010-01-01

\title{
Fabrication and Characterizations of YSZ Electrolyte Films for SOFC
}

\author{
Han, M-F
}

http://hdl.handle.net/10026.1/3263

10.4028/www.scientific.net/KEM.434-435.705

HIGH-PERFORMANCE CERAMICS VI

TRANS TECH PUBLICATIONS LTD

All content in PEARL is protected by copyright law. Author manuscripts are made available in accordance with publisher policies. Please cite only the published version using the details provided on the item record or document. In the absence of an open licence (e.g. Creative Commons), permissions for further reuse of content should be sought from the publisher or author. 


\title{
Fabrication and Characterizations of YSZ Electrolyte Films for SOFC
}

\author{
Min-Fang Han ${ }^{1, a}$, Zhibin Yang ${ }^{1}$, Ze Liu' ${ }^{1}$, Hui-Rong Le ${ }^{2}$ \\ ${ }^{1}$ Union Research Center of Fuel Cell, School of Chemical \& Environment Engineering, \\ China University of Mining \& Technology, Beijing, 100083, P.R. China \\ ${ }^{2}$ School of Engineering, Physics and Mathematics, University of Dundee, Dundee DD1 4HN, \\ United Kingdom \\ a hanminfang@sina.com
}

Keywords: SOFC; Yttria stabilized zirconia; electrolyte

\begin{abstract}
Yttria stabilized zirconia (YSZ) has been widely used as electrolyte in solid oxide fuel cell (SOFC). The effect of fabrication process on the properties of YSZ electrolyte thick film is discussed in the paper. With YSZ nano-powders of about 20-60nm as raw material, YSZ green adobe was fabricated by tape calendering process. Three-step sintering process was performed firstly holding at $1000^{\circ} \mathrm{C}$ for $2 \mathrm{~h}$, then raising to $1300 \sim 1400^{\circ} \mathrm{C}$, then decreasing to $1200 \sim 1300^{\circ} \mathrm{C}$ within 30 minutes, and finally calcining at $1200 \sim 1300^{\circ} \mathrm{C}$ for $5 \sim 20 \mathrm{hrs}$. Dense YSZs with relative density of $96-99 \%$ are obtained; the grain size of YSZ was reduced to $0.5-3 \mu \mathrm{m}$. During the process of grain growth, there are both grain boundary diffusion and grain boundary migration. The feasibility of densification without grain growth relies on the suppression of grain boundary migration while keeping grain boundary diffusion active at a temperature as low as $1200 \sim 1300^{\circ} \mathrm{C}$. Whereas the electric conductivities of the YSZs are even higher than that obtained in conventional single step sintering process. The process is applied to the anode-supported SOFCs co-fired at $1250 \sim 1300^{\circ} \mathrm{C}$, and the cathode-supported SOFCs co-fired at $1200 \sim 1250^{\circ} \mathrm{C}$.
\end{abstract}

\section{Introduction}

$8 \mathrm{~mol} \%$ Yttria stabilized zirconia (YSZ) is the most popular electrolyte material in solid oxide fuel cell (SOFC) [1,2], in which the anode is $\mathrm{Ni} / \mathrm{YSZ}$ and the cathode is doped lanthanum manganite (LSM)/YSZ. In electrolyte-supported SOFC, the thickness of YSZ electrolyte is generally $150 \sim 300$ $\mu \mathrm{m}$, which operates during $800 \sim 1000^{\circ} \mathrm{C}$ [3]. In electrode-supported SOFC, the thickness of YSZ electrolyte is generally $15 \sim 30 \mu \mathrm{m}$, which operates during $600 \sim 800^{\circ} \mathrm{C}$ [3]. It is important for the three layers of Ni/YSZ-YSZ-YSZ/LSM to co-fire together in SOFC, which is helpful to reduce the interlayer resistance and lower the manufacture cost. But, at present, the NiO/YSZ anode and YSZ electrolyte are co-fired during $1350-1450^{\circ} \mathrm{C}$ [4-7] and the YSZ electrolyte and LSM/YSZ cathode are required to co-fire during $1200-1250^{\circ} \mathrm{C}$ [8-12]. So, it is necessary to lower the sintering temperature of YSZ electrolyte to $1200-1300^{\circ} \mathrm{C}$ in order to co-fire the three layers of Ni/YSZ-YSZ-YSZ/LSM in SOFC. Because the thickness of YSZ electrolyte is generally $10 \sim 15 \mu \mathrm{m}$ in electrode-supported SOFC, the grain size of YSZ electrolyte layer is very important. However, due to higher surface energy of YSZ grains, YSZ grains tend to grow large in the sintering process [13]. Therefore, it is urgent to develop a novel sintering process for YSZ electrolyte films to obtain a desirable fine microstructure.

\section{Materials and Methods}

With the zirconium and yttrium nitrate hydrate ( $>99.99 \%$ pure, Baotou, China) as the cation sources, and ammonia (25\%, A.R., Beijing, China) as the precipitation, the precursors for 8 YSZ powders were precipitated first by dripping the salt solutions into an ammonia solution under mild stirring until $\mathrm{pH} \approx 8 \sim 9$. Then the suspended solution was washed repeatedly with distilled water followed by drying at room temperature. Finally, the dried precursors were then calcined at $600 \sim 650^{\circ} \mathrm{C}$ for $2 \mathrm{~h}[14]$. 
The powders were characterizated using HITACHI-H8100 TEM. The range of powder distribution was measured by SA-CP3 sedimentation centrifuge. The sintering behavior of the powders were analyzed by Netzsch Dil402C type thermal analyzer. The green adobes of YSZ with the thickness of $150-200 \mu \mathrm{m}$ were made by tape calendaring process [TCL] with $30 \%$ polyvinyl alcohol (PVA) and 6\% glycerine added into the powders [15]. The samples were punched into pellets with diameter of $20 \mathrm{~mm}$ and thickness of $150-200 \mu \mathrm{m}$.

The YSZ electrolyte films were sintered at $1200-1300^{\circ} \mathrm{C}$ in a high temperature box furnace (type-GXL-34/30/40). The density was measured according to Archimedes method. The grain size and microstructure were observed on SEM (GSM6700, Japanese). The electrical conductivity of YSZ electrolytes was measured via 4-probe DC technique. The AC impedance analyzer (Agilent 4294A) was used for the $\mathrm{AC}$ impedance measurement over the frequency range of $40 \mathrm{~Hz}-110 \mathrm{MHz}$.

\section{Results and Discussion}

Sintering process of YSZ. With the YSZ nano-powders as the raw materials, the grain size of YSZ powder is around $20 \sim 60 \mathrm{~nm}$, the mode diameter is $0.155 \mu \mathrm{m}$, the median diameter $\left(\mathrm{d}_{50}\right)$ is $0.153 \mu \mathrm{m}$ and the $\mathrm{d}_{90}$ is $0.183 \mu \mathrm{m}$. The BET surface area is $15.2 \mathrm{~m}^{2} / \mathrm{g}$. The powders are uniform spherical and there are no hard agglomerates in them. These powders with uniform grain size and narrow grain distribution have the good sintering properties. The initial sintering temperature of YSZ powder is $990.5^{\circ} \mathrm{C}$, which is relative to the grain size [16]. During the sintering processes, from $990.5^{\circ} \mathrm{C}$ to $1400^{\circ} \mathrm{C}$, the fastest sintering rate of the $\mathrm{YSZ}$ occurs at $1325.7^{\circ} \mathrm{C}$, and the whole sintering process is completely finished at $1400 \sim 1450^{\circ} \mathrm{C}$.

According to the sintering behavior of YSZ powders reported previously, three-step sintering process was pointed out for YSZ sintering. The temperature was raised at a rate of $(60 \sim 100){ }^{\circ} \mathrm{C} / \mathrm{h}$ from R. T. to $1000^{\circ} \mathrm{C}$, then held at $1000^{\circ} \mathrm{C}$ for 2 hours, then raised the temperature to $1300 \sim 1400^{\circ} \mathrm{C}$ at a rate of $50^{\circ} \mathrm{C} / \mathrm{h}$ followed by rapid decrease to $(1200 \sim 1300){ }^{\circ} \mathrm{C}$ and finally the furnace was held at (1200 1300) ${ }^{\circ} \mathrm{C}$ for 5 20 hours [17].

During the sintering process of YSZ, the first step is related to the nucleation of YSZ crystals at a temperature of about $1000^{\circ} \mathrm{C}$. The YSZ nuclei are formed by surface diffusion, which overcomes the barrier of the surface energy [17]. There is an initial crystallite (nuclei) size $d_{c}$. Only those grains with the size of YSZ nuclei $d \geq d_{c}$ will grow in the later grain growth steps. Therefore it is necessary to hold a period of time (e.g. $2 \mathrm{~h}$ ) at about $1000^{\circ} \mathrm{C}$, which helps to form a large number of nuclei with size larger than $d_{c}[18,19]$. These nuclei will grow in the following steps.

The second step in the sintering processes of YSZ, is related to grain growth at a temperature from $1000^{\circ} \mathrm{C}$ to $1400^{\circ} \mathrm{C}$ [17], because the grain growth needs a higher energy. The grain growth is associated with grain boundary motion, which is mainly controlled by grain boundary migration in higher energy state. The grain boundary migration would lead to grain growth quickly, so it is necessary to limit the time at the high temperature of $1400^{\circ} \mathrm{C}$. The ideal process is that to lower the temperature to the required temperature in the range of $1200 \sim 1300^{\circ} \mathrm{C}$ as soon as it reaches $1400^{\circ} \mathrm{C}$. At this stage, the relative density of YSZ is about $80 \%$.

The third step in the sintering processes of YSZ is related to densification behavior of the green body at lower temperature of $1200 \sim 1300^{\circ} \mathrm{C}$ [17]. As we know, the grain growth behavior contains two processes: grain boundary diffusion and grain boundary migration. At relatively low temperature, according to Harmer and Brook [20], grain boundary diffusion may proceed; while at high temperatures, grain boundary migration becomes a dominant mechanism for grain growth. It is suggested that grain boundary migration may involve an activation process that needs higher activation energy than grain boundary diffusion. The feasibility of densification without grain growth relies on the suppression of grain boundary migration while keeping grain boundary diffusion active [21]. When the temperature is holding at $1200-1300^{\circ} \mathrm{C}$, at which grain boundary migration is limited but grain boundary diffusion prevails. As a result, the YSZ grain size is limited in a certain range, 


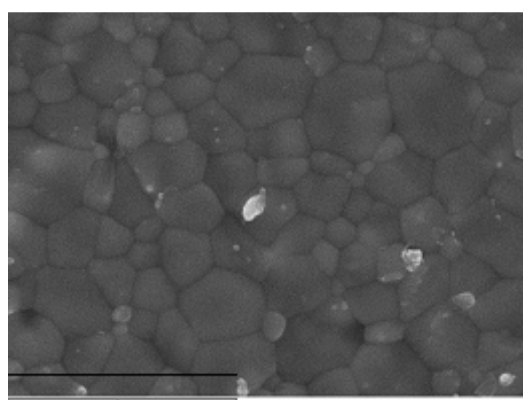

A $1.1300^{\circ} \mathrm{C} \times 8 \mathrm{~h}($ surface $)$

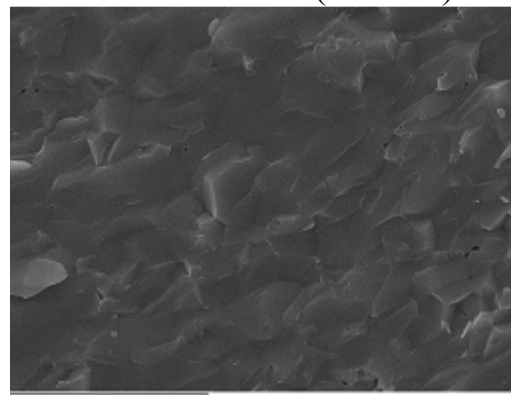

B2. $1250^{\circ} \mathrm{C} \times 10 \mathrm{~h}($ cross section $)$

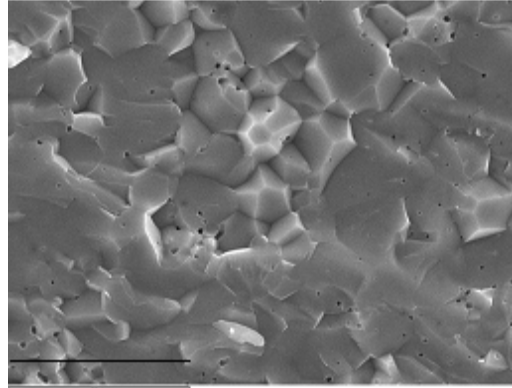

$\mathrm{A} 2.1300^{\circ} \mathrm{C} \times 8 \mathrm{~h}($ cross section $)$

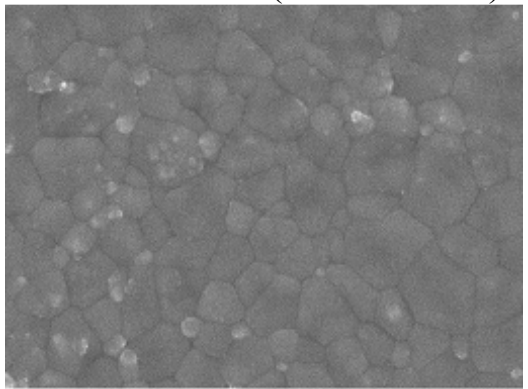

$\mathrm{C} 1.1200^{\circ} \mathrm{C} \times 10 \mathrm{~h}($ surface $)$

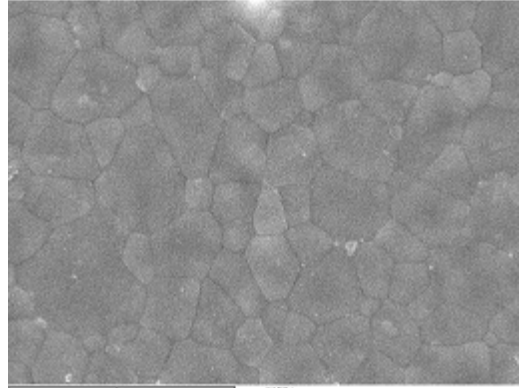

$\mathrm{B} 1.1250^{\circ} \mathrm{C} \times 10 \mathrm{~h}($ surface $)$

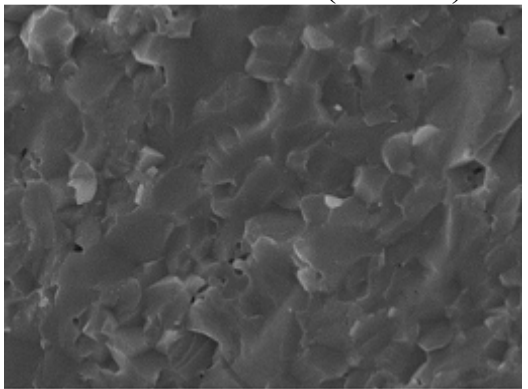

$\mathrm{C} 2.1200^{\circ} \mathrm{C} \times 10 \mathrm{~h}($ cross section $)$

Fig. 1 Microstructure of YSZ electrolyte sintered at $1200 \sim 1300^{\circ} \mathrm{C}$
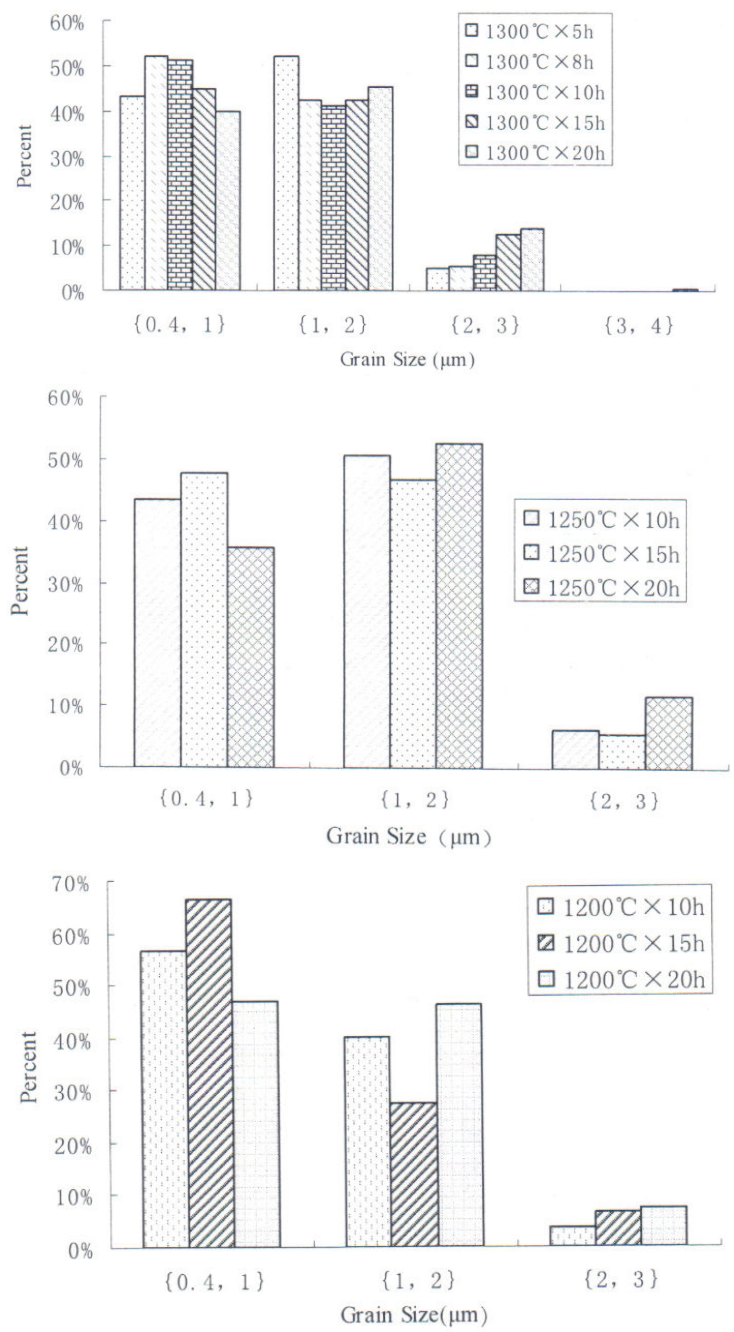

Fig.2 The grain size distribution of YSZ electrolyte sintered at $1200 \sim 1300^{\circ} \mathrm{C}$ mostly below $1 \mu \mathrm{m}$. In this way, the YSZ grain size does not increase as dramatically as in conventional sintering method, but dense ceramic bodies are obtained. In order to ensure the sufficiency of grain boundary diffusion, relatively long time such as $10-20$ hours are needed at $1200-1300^{\circ} \mathrm{C}$. In the end, dense YSZs with the relative density higher than $96 \%$ were obtained.

Microstructure of YSZ films. The microstructure on surface and cross section of YSZ sintered at various conditions are shown in the Fig.1. In the dense YSZ samples, the grains are uniform and the grain boundaries are straight, clear and thin. From the surface microstructure, there are almost no pores. While from the cross section microstructure, a few pores are evident, some of which are inside the grains and others are in the grain boundary. The pores are minute and enclosed, which have little effect on the electrical conductivities of YSZ discussed later.

The grain size and size distribution of YSZ are shown in Fig.2. The size distribution of YSZ is in the range of $0.4 \sim 3 \mu \mathrm{m}$, most of them are less than $1 \mu \mathrm{m}$. At the same sintering temperature, the grain size becomes bigger when the holding time is longer. With the same holding time, the grain size increases with the sintering temperature increasing. There are three ranges of grain size: $0.4-1 \mathrm{~m}, 1-2 \mu \mathrm{m}, 2-3 \mu \mathrm{m}$. Only when sintered at $1300^{\circ} \mathrm{C}$ for $20 \mathrm{~h}$, there are a few grains bigger than $3 \mu \mathrm{m}$. In the YSZ smaples sintered at $1200^{\circ} \mathrm{C}$, the quantity of grain size below 

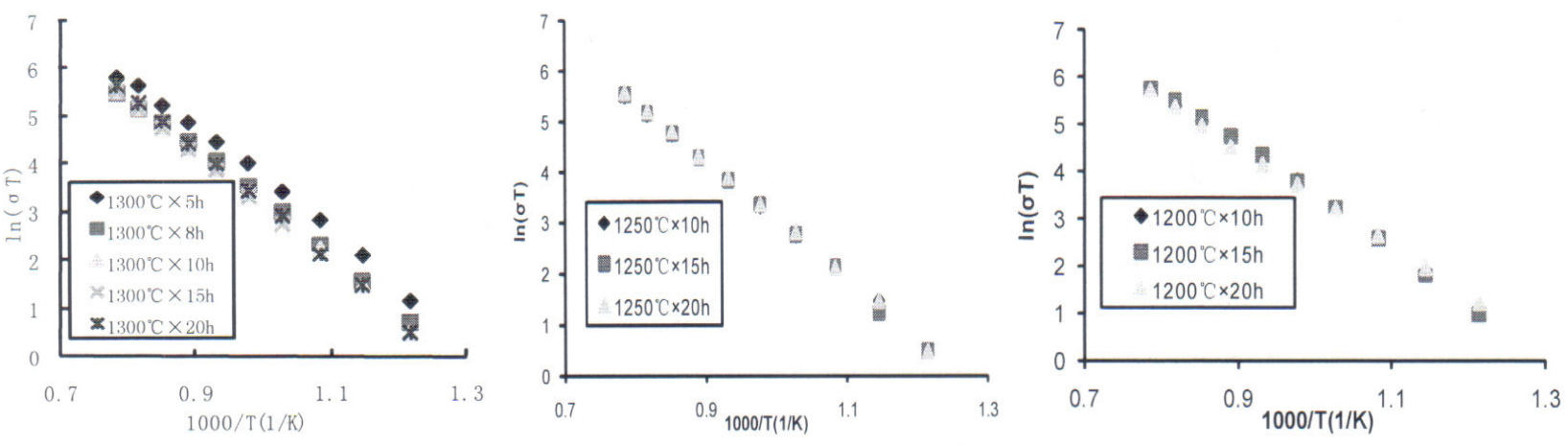

Fig. 3 The electrical conductivity of YSZ sintered at $1200 \sim 1300^{\circ} \mathrm{C}$

$1 \mu \mathrm{m}$ is more than $50 \%$. The sub-micrometer grains in YSZ electrolytes are important to the electrodesupported SOFC, in which the desirable YSZ electrolyte films are less than $10 \mu \mathrm{m}$.

Electrical properties of YSZ. The electrical conductivities of YSZ prepared in different sintering processes are shown in Fig.3. It is indicated that the electrical conductivities are very similar. The electrical conductivities of YSZ at different temperature are higher than the report data [4].

When the grain size becomes smaller, the electrical conductivity does not decrease but becomes much higher. For dense ceramic solid electrolyte, the effect of pores is negligible. The conductivity of solid electrolyte is made up of grain conductivity and grain boundary conductivity. In view of traditional solid state ionic conductive theory, grain conductivity is two or three times higher than that of the grain boundary [22-24]. The properties of intergranular region play an important role in the overall conductivity of the electrolyte. The poor conductivity of the electrolyte is usually due to the low conductivity of the intergranular region. Many factors, such as grain size, intergranular area, impurity level and intergranular thickness, significantly affect on the apparent intergranular conductivity. It is suggested that there are two main reasons for low grain-boundary conductivity. Firstly, there is a space-charge layer near the grain boundary formed by solute segregation or a blocking layer for oxygen conducting formed by impurity phase. The other is that the conduction of oxygen ions decreases when the oxygen-vacancy concentration at the grain boundary is lower than in the grain interior [22].

In YSZ electrolyte, as YSZ grain size becomes smaller and smaller, the thickness of intergranular region decreases greatly. There are only several atom layers in the intergranular region, where there is hardly the solute segregation or impurity phase in the region to form the blocking layer for oxygen ion conducting. It is assumed that the oxygen-vacancy concentration at the grain boundary for oxygen ions conducting is not lower, but higher. So the intergranular conductivity would increase. Since the density is still high, the intragranular conductivity which is mainly depended on the density does not change significantly, as shown in Fig 8 . Therefore, the total conductivity is improved.

In comparison of the electrical conductivities of YSZ sintered at different processes, the desirable sintering process is the $1200^{\circ} \mathrm{C} \times 10 \mathrm{~h}$, in which the electrical conductivities of YSZ are higher, i.e. $0.04 \mathrm{~s} / \mathrm{cm}$ at $800^{\circ} \mathrm{C}$ and about $0.2 \mathrm{~s} / \mathrm{cm}$ at $1000^{\circ} \mathrm{C}$, than previously reported $\left(0.006600^{\circ} \mathrm{C}, 0.12 \mathrm{~s} / \mathrm{cm}\right.$ at $\left.1000^{\circ} \mathrm{C}{ }^{\circ} \mathrm{C}[4]\right)$.

With the above low-temperature sintering process of YSZ, the electrode supported half cell could be made by co-firing processes [5]. In the anode-supported half cell, the Ni/YSZ cermet and YSZ were sintered together at $1250^{\circ} \mathrm{C}$. The densitive YSZ electrolyte film with a thickness of $15 \mu \mathrm{m}$ coheres tightly with the porous matrix of Ni/YSZ cermet. The grain size of YSZ film is about $0.2-1.5 \mu \mathrm{m}$. In the cathode-supported half cell, the porous LSM/YSZ and YSZ were sintered together at $1250^{\circ} \mathrm{C}[11]$. The thickness of the electrolyte is approximately $10 \sim 15 \mu \mathrm{m}$ and the adhesion between the substrate and the electrolyte is good. 


\section{Conclusions}

The sub-micrometer grain sizes such as $0.4-3 \mu \mathrm{m}$ in YSZs are obtained by a three-step sintering process. The grain size became larger with the increase of temperature $1200 \sim 1300^{\circ} \mathrm{C}$ and holding time $5 \sim 20 \mathrm{~h}$. The grain size less than $1 \mu \mathrm{m}$ is up to $65 \%$ when sintered at $1200^{\circ} \mathrm{C}$ for $15 \mathrm{~h}$, the largest grains from each sintering schedule is $2-3 \mu \mathrm{m}$, which is less than $10 \%$. During the third sintering step at $1200 \sim 1300^{\circ} \mathrm{C}$, the decreased temperature can suppress grain boundary migration but not affect grain boundary diffusion. As a result, the relative density is more than $96 \%$, and the grain size in sub-micrometer range dominates. So the thickness of intergranular region decreases greatly, and there is not enough solute segregation or impurity phase in the region to form the blocking layer for oxygen ion conducting. Therefor the electrical conductivity is as high as $0.04 \mathrm{~s} / \mathrm{cm}$ at $800^{\circ} \mathrm{C}$, and more than $0.2 \mathrm{~s} / \mathrm{cm}$ at $1000^{\circ} \mathrm{C}$. The above result makes it possible to co-fire the anode-supported SOFCs at $1250 \sim 1300^{\circ} \mathrm{C}$ and the cathode-supported SOFCs at $1200 \sim 1250^{\circ} \mathrm{C}$.

\section{Acknowledgements}

Financial support from the NSFC (50730004, 50872150,) of China, MOST Program (2009DFA6136, 2006AA05Z148) of China and MOE Project (NCET-06-0203) of China are appreciated.

\section{References}

[1] N.Q.Minh and T. Takahashi: Science and Technology of Ceramic Fuel Cells, Elsevier Science B. V., Amsterdam, The Netherland, 1995.

[2] M. F. Han, S. P. Peng: Materials and fabrication of solid oxide fuel cells, Science Press, Beijing,2004 2, (In Chinese).

[3] S. C. Singhal and K. Kendall: High Temperature Solid Oxide Fuel Cells: Fundamentals, Desigh and Applications, Elsevier Advanced Technology, Oxford, UK, 2004.

[4] R. N. Basu, G. Blass: J. Eur. Ceram. Soc. Vol. 25 (2005), p. 463-471.

[5] M. F. Han, H. Y. Yin, W. T. Miao, S. Zhou: Solid State Ionics, Vol. 179 (2008), p. 1545-1548

[6] W. T. Miao, M. F. Han, H. Y. Yin: Rare Met. Mater. Eng. Vol. 37(1) (2007), p. 431-434 (In Chinese).

[7] M. F. Han, C. B. Yang, L. J. Huo, S. P. Peng: Rare Met. Mater. Eng. Vol: 34(1) (2005), p. 657-661.

[8] H. Orui, K. Watanabe, M. Arakara: J. Power Sources. Vol. 112 (2002), p. 90-97.

[9] K. Yamahara, C. P. Jacobson, S. J. Visco, et al.: Solid State Ionics. Vol. 176 (2005), p. 451-456.

[10] S. D. Souza, S. J. Visco, L. C. De Jonghe: Solid State Ionic. Vol. 98 (1997), p. 57-61.

[11] H. Y. Yin, M. F. Han, W. T. Miao: IOM East Asia - 6th Materials Processing, Properties and Performance (MP3) conference 13-16 September, 2007 Beijing, China, p. 1051.

[12] M. M. Han, S. P. Peng, H. Y. Yin: Chinese Patent ZL 100805970 (2006).

[13] J. L. Shi, M. L. Ruan and T. S. Yen: Ceram. Inter. Vol. 22(1996), p. 137-142.

[14] H. Y. Yin, M. F. Han: Key Eng. Mater. Vol. 336-338(2007), p. 2558-2561.

[15] M. F. Han, C. B. Yang, B. T. Li, S. P. Peng: Battery. Vol.34(3) (2004), p. 207-208.

[16] M. F. Han, S. P. Peng, B. T. Li: Rare Met. Mater. Eng. Vol. 32(1) (2003), p. 491-495.

[17] M. F. Han, X. L. Tang, H. Y. Yin, S. P. Peng: J. Power Sources. Vol. 165 (2007), p.757-763.

[18] M. F. Han, L. J. Huo, B. T. Li, S. P. Peng: J. Uni. Sci. Tech. Beijing. Vol. 12(1): (2005), p.78-80.

[19] M. F. Han, B. T. Li, S. P. Peng: J. Wuhan Uni. Tech. Mater. Sci. Vol. 19(3) (2004), p. 10-13.

[20] M. P. Harmer, R. J. Brook: J. Brit Ceram. Soc. Vol. 80(5) (1980), p. 147.

[21] I. W. Chen, X. H.Wang: Nat. Vol. 404 (2000), p. 168-171.

[22] X. Guo, R.Waser: Prog. Mater. Sci. Vol. 51 (2006), p. 151-210.

[23] X. J. Chen, K. A. Khor, S. H. Chan et al: Mater. Sci. Eng. A. Vol. 335 (2002), p. 246-252.

[24] P. Mondal, A. Klein, W. Jaegermann, et al.: Solid State Ionics. Vol.118 (1999), p. 331-339. 